Original Research Paper

\title{
Using Bioethanol Wastes as an Alternative Phosphorus Source for Snap Bean and Radish Production
}

\author{
${ }^{1}$ Xiaolin Liao, ${ }^{1}$ Ben Hogue, ${ }^{1}$ Shouliang Zhu, ${ }^{2}$ Zhaohui Tong, ${ }^{1}$ Guodong Liu and ${ }^{3}$ Yuncong Li \\ ${ }^{1}$ Department of Horticultural Sciences, IFAS, University of Florida, Gainesville, FL 32611, USA \\ ${ }^{2}$ Department of Agricultural and Biological Engineering, IFAS, University of Florida, Gainesville, FL 32611, USA \\ ${ }^{3}$ Department of Soil and Water Science, Tropical Research and Education Center, \\ IFAS, University of Florida, Homestead, FL 33031, USA
}

\author{
Article history \\ Received: 22-05-2015 \\ Revised: 07-09-2015 \\ Accepted: 16-01-2016 \\ Correspondng Author: \\ Guodong Liu \\ Department of Horticultural \\ Sciences, IFAS, University of \\ Florida, Gainesville, FL 32611, \\ USA \\ Tel: $352-273-4814$ \\ Fax: 352-846-0909 \\ Email: guodong@ufl.edu
}

\begin{abstract}
Biorefinery waste has potential to provide alternative sources of phosphorus (P) for plant industry if biomass has been pretreated by phosphoric acids during its production process. In this study, we investigated the potential of the fermentation waste from a bioethanol process as a $\mathrm{P}$ fertilizer. Three treatments were set up for growing crops of snap bean (var., Bronco) and radish (var., Crimson Giant), i.e., P source as fermentation wastes from bioethanol production, commercial $\mathrm{P}$ fertilizer as triple superphosphate containing 44\% P2O5 and control without any P fertilizer. The yields, biomass and leaf greenness of two crops were measured. Results showed that higher leaf greenness, yields and biomass were observed for the crops treated with fermentation wastes, suggesting the wastes from bioethanol production have the potential as $\mathrm{P}$ fertilizer. However, more related researches in a large scale will be needed in the future.
\end{abstract}

Keywords: Bioethanol Fermentation Wastes, Phosphorus Fertilizer, Snap Bean, Radish

\section{Introduction}

Bioethanol is the most extensively-used biofuel for transportation around the world (Ward and Singh, 2002; Ibeto et al., 2011). Florida became the home to the first commercial-scale cellulosic ethanol project in the United States in 2013 (Postelwait, 2013). The technology to produce bioethanol from renewable resources such as starch, sweet sorghum extractives and lignocelluloses has been extensively explored (Willington and Marten, 1982). Sugarcane bagasse is used as feedstock for biofuel production and consisted of $45-55 \%$ cellulose, $20-25 \%$ hemicelluloses, $18-24 \%$ lignin, $1-4 \%$ ash and $1 \%$ wax (Rainey et al., 2009). Thus, bagasse itself doesn't contain much phosphorus (P) but during the pretreatment process, dilute phosphoric acid is generally added (Wyman et al., 2005; Zeng et al., 2014). As biofinery fermentation industry wastes are generated in huge quantities in a short period of time, a main environmental problem represents in the entire biofuel production processes (Vijayaraghavan and Yun, 2007). There are many concerns for large-scale ethanol development, such as how to deal with the waste or the by-product from the fermentation-distillation process
(Willington and Marten, 1982; Kim and Dale, 2004; Mustafa et al., 2008). It has been reported that the biofuel waste has a considerable pollution potential (Sheehan and Greenfield, 1980; Ward and Singh, 2002).

Handling the waste correctly is important not only for a scale-up process but also for sustainable environment. The use of the waste may also add value to current bioethanol processes (Willington and Marten, 1982; Wilkie et al., 2000; Kim and Dale, 2004; Mustafa et al., 2008). Several approaches have been discussed about handling the regular wastes such as conventional sewage treatments, returning to agricultural fields as fertilizers and using as an animal or aquaculture feed (Sheehan and Greenfield, 1980; Willington and Marten, 1982; Sahai et al., 1983; Driessen et al., 1994; Wilkie et al., 2000; Kolár et al., 2008). Biofuel waste is also a potential commodity for the fertilizer/agriculture market since the waste is generally rich in nutrients essential for plant growth and development (Moore, 2011). Thus, if the waste can be used as a phosphate fertilizer, then it is not only unnecessary to be treated but also a good Pfertilizer source for agriculture. Particularly, as P rock is depleting and will be run out in a few decades, a 
potential P crisis is on the horizon (Abelson, 1999; Cordell et al., 2009), using biofuel waste to provide $\mathrm{P}$ nutrient will be beneficial. The objective of this study was to evaluate the effects of the fermentation waste from biofuel production on the yields, biomass and leaf greenness of snap bean and radish.

\section{Methods and Materials}

\section{Fermentation Waste Collection}

The fermentation waste (approximately $25 \%$ solid) from the Stan Mayfield Biorefinery Pilot Plant in Perry, Florida was collected. This pilot plant produced the bioethanol through a phosphoric acid catalyzed steam explosion pretreatment process followed by a Liquefaction plus Simultaneously Saccharification and Co-fermentation Process (L plus SSCF) and sugarcane bagasse was used as the feedstock. This waste has approximately $300 \mathrm{mg} \mathrm{L}^{-1}\left(354 \pm 59 \mathrm{mg} \mathrm{kg}^{-1}\right)$ available $\mathrm{P}$ and $<1 \mathrm{mg} \mathrm{L}^{-1}\left(0.4 \pm 0.1 \mathrm{mg} \mathrm{kg}^{-1}\right)$ nitrogen $(\mathrm{N})$ with $\mathrm{pH} 6.2 \pm 0.4$. It was diluted to $10 \mathrm{mg} \mathrm{L}^{-1}$ phosphorus pentoxide $\left(\mathrm{P}_{2} \mathrm{O}_{5}\right)$ with de-ionized water and then applied as P fertilizer to snap bean (var., Bronco) and radish (var., Crimson Giant) plants grown in pots.

\section{Pot Experiment}

The experiment was conducted using a randomized complete block with two treatments and four replications for snap bean and five replications for radish. Each replication had six pots for snap bean and five pots for radish, respectively. The pot size was 3,200 $\mathrm{ml}$. Each pot was filled with sandy soil collected from the University of Florida Plant Science Research and Education Unit near Citra, FL, USA. The soil was classified as Candler sand with 97\% sands (Buster, 1979; Zotarelli et al., 2011). Plant available (Olsen extractable) nutrients ( $\mathrm{mg}$ $\mathrm{kg}^{-1}$ ) in this soil were $20 \mathrm{mg} \mathrm{kg}^{-1} \mathrm{P}, 18 \mathrm{mg} \mathrm{kg}^{-1} \mathrm{~K}, 422$ $\mathrm{mg} \mathrm{kg}{ }^{-1} \mathrm{Ca}, 45 \mathrm{mg} \mathrm{kg}^{-1} \mathrm{Mg}$. Other basic properties of this soil were $\mathrm{pH} 6.3$; soil bulk density $1.5 \mathrm{~g} \mathrm{~cm}^{-3}$; soil organic matter $1.0 \%$; CEC, $2.8 \mathrm{cmol} \mathrm{kg}^{-1}$.

Each pot had one plant for snap bean and 2 plants for radish. The treatments were paralleled with a control without $\mathrm{P}$ fertilization. The two treatments were (1) fermentation wastes without $\mathrm{P}$ fertilization; (2) commercial $\mathrm{P}$ fertilizer as triple superphosphate containing $44 \%$ of $\mathrm{P}_{2} \mathrm{O}_{5}$. The fertilizer application rates were based on the Institute of Food and Agricultural Sciences (IFAS) recommendations (Olson et al., 2013; Ozores-Hampton et al., 2013). The N, P and K application rates $\left(\mathrm{kg} \mathrm{ha}^{-1}\right)$ were 112,134 and 134 for snap bean, as well as 101, 112 and 112 for radish, respectively. The fertilizers were applied in liquid twice a week to snap bean for five weeks and to radish for three weeks. Snap bean was planted on September $10^{\text {th }}, 2012$ and harvested on
November $7^{\text {th }}, 2012$. Radish were seeded on August $20^{\text {th }}$ and harvested on September 24 $4^{\text {th }}, 2012$.

\section{Leaf Greenness, Yields and Biomass}

Leaf chlorophyll concentrations were measured with a SPAD-502 meter (Konica-Minolta, Osaka, Japan) at harvest. Beans and radish were removed from the plants and weighed fresh as the yields. Biomass accumulation at harvest was determined by cutting plant stems at the soil surface for each pot. The entire plant of radish or the shoot and beans of snap bean were oven-dried at $70^{\circ} \mathrm{C}$ until constant weight was achieved.

\section{Statistic Analysis}

Data were analyzed using one-way ANOVA method (SAS Institute, 2009) and was considered significant at $p$ $<0.05$. After running the SAS program, the critical ranges $\left(\mathrm{LSD}_{2}, 0.05\right)$ of Duncan's Multiple Range Test were used to detect the difference significance between two means (Hubbard, 2001).

\section{Results and Discussion}

\section{Leaf Greenness}

The SPAD chlorophyll meter measures transmittance of red and infrared light through the leaf and displays a number that is proportion to chlorophyll concentrations in the leaf (Hoel, 1998). The results showed that the leaf greenness of snap bean with the fermentation waste treatment was significantly $(\mathrm{p}<0.05)$ greater than those of the commercial fertilizer treatment and the control but the latter two were not significantly different. Similarly, radish plants treated with the biofuel waste had significantly greater leaf greenness than those with $\mathrm{P}$ fertilizer. The latter was significantly greater than those of the control (Fig. 1). The exact compositions of the fermentation wastes depend on the raw material and distillation techniques. Generally, the compositions have high concentrations of Biological Oxygen Demand (BOD) and nutrients (Willington and Marten, 1982; Callander et al., 1986; Wilkie et al., 2000). For the fermentation wastes used in this research, high $\mathrm{P}$ concentration $\left(\sim 300 \mathrm{mg} \mathrm{L}^{-1}\right)$ was observed but the $\mathrm{N}$ content was low $\left(<1 \mathrm{mg} \mathrm{L}^{-1}\right)$. Others, however, have measured high $\mathrm{N}$ contents in other bioethanol wastes (Moore, 2011; Galvez et al., 2012). Some of the literature indicated that there was a positive relationship between leaf chlorophyll concentration and leaf $\mathrm{N}$ content in agricultural crops (Wood et al., 1992; Turner and Jund, 1994; Percival et al., 2008). In this study, the greater SPAD readings of the fermentation wastes may be related to possible increase in nutrient and water holding capacity in sandy soils by the fermentation wastes (Wang et al., 2014). These possible compounds were not able to be detected in this study. 

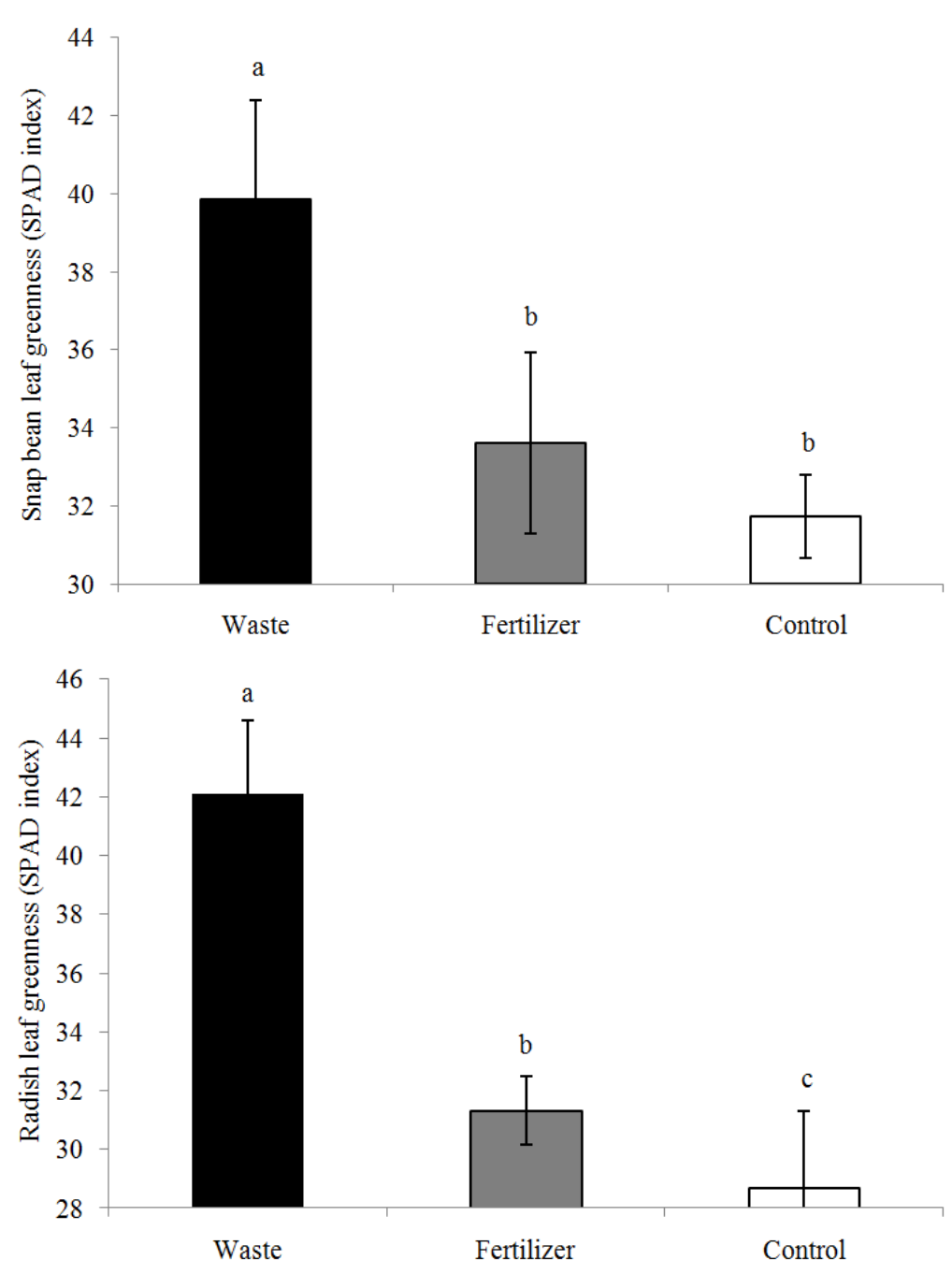

Fig. 1. Differences in the leaf greenness of snap bean and radish treated with the fermentation waste, commercial $\mathrm{p}<0.05$ fertilizer treatments and control without phosphorus fertilizer. Different lowercase letters on histograms denote significant difference $(\mathrm{p}<0.05)$. $\mathrm{LSD}_{0.05,2}$ was 4.08 and 2.02 for snap bean and radish, respectively

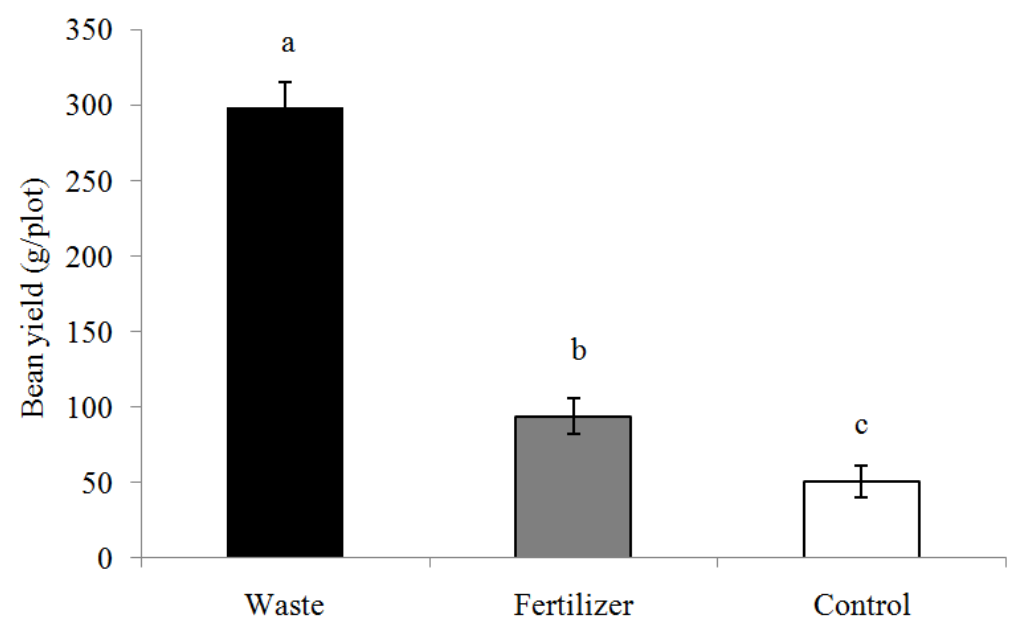

Fig. 2. Differences in bean yield of snap bean and radish treated with the fermentation waste, commercial $P$ fertilizer treatments and control without $P$ fertilizer. Different lowercase letters on histograms denote significant difference $(\mathrm{p}<0.05)$. $\operatorname{LSD}_{0.05,2}=16.2$ 


\section{Yields and Biomass}

The results showed that the yield of snap bean treated with the fermentation waste $(298 \pm 17 \mathrm{~g} / \mathrm{plot})$ was significantly greater than those the P-fertilizer treatment $(94 \pm 6 \mathrm{~g} / \mathrm{plot})$ and the control without $\mathrm{P}$ fertilizer $(51 \pm 10$ $\mathrm{g}$ /plot, $\mathrm{p}<0.05$, Fig. 2). Similarly, the biomass of the beans among the treatments was significantly different following this order: the fermentation waste treatment $>$ the P-fertilizer treatment $>$ the control. However, for the shoot biomass, only the waste treatment was significantly greater than the other two (Fig. 3). This significant difference may be attributed to that the fermentation wastes appeared to divert more photosynthetic assimilates to the beans and hence, increase the bean/shoot ratio significantly as compared with the P-fertilizer treatment. The latter had in turn significantly greater bean/shoot ratio than the control (Fig. 4).

Similarly, both fresh yield and biomass of radish with the fermentation waste were significantly greater than those with the control (Fig. 5). However, the P-fertilizer treatment and control did not show any significantly differences in both fresh yield and biomass. The fermentation waste has also been reported as a quality soil amendment to improve the physical and chemical properties of soil besides the nutrient effects. For example, Wang et al. (2014) found that the amendment of fermentation waste from a bioethanol process was able to significantly improve water retention and reduce $\mathrm{N}$ and $\mathrm{P}$ in the leachate for a sandy soil. The soil quality improvement would be also expected to increase crop yields even though the exact effects of the waste on soil properties were not examined in this study.

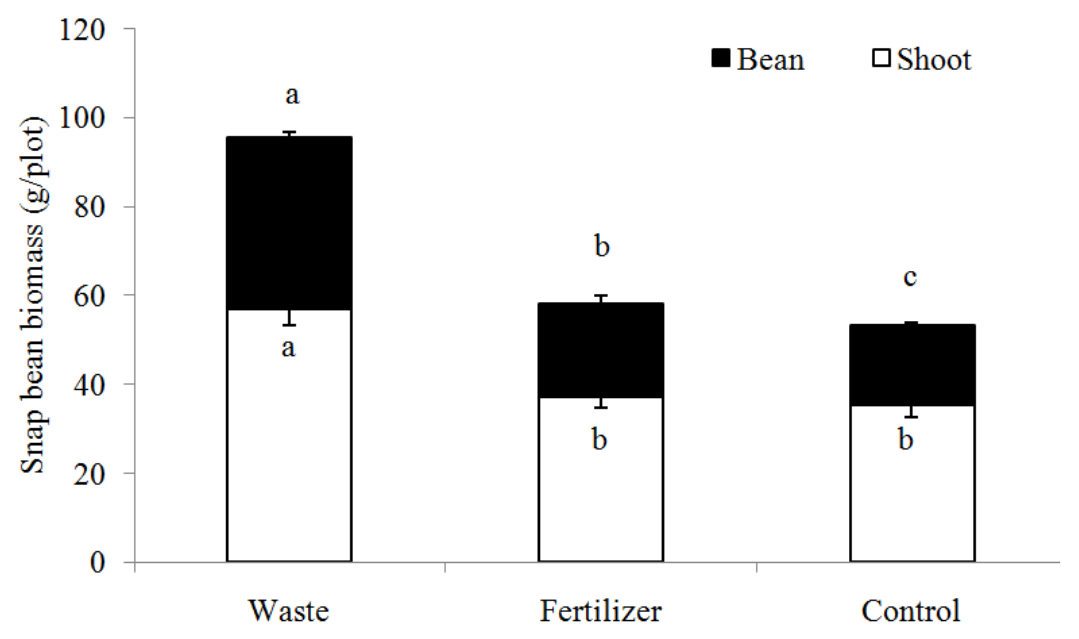

Fig. 3. Differences in biomass of snap bean treated with the fermentation waste, commercial P fertilizer treatments or control without P fertilizer. Different lowercase letters on histograms denote significant difference $(\mathrm{p}<0.05)$. $\operatorname{LSD}_{0.05,2}$ was 2.6 and 5.4 for beans and shoots, respectively
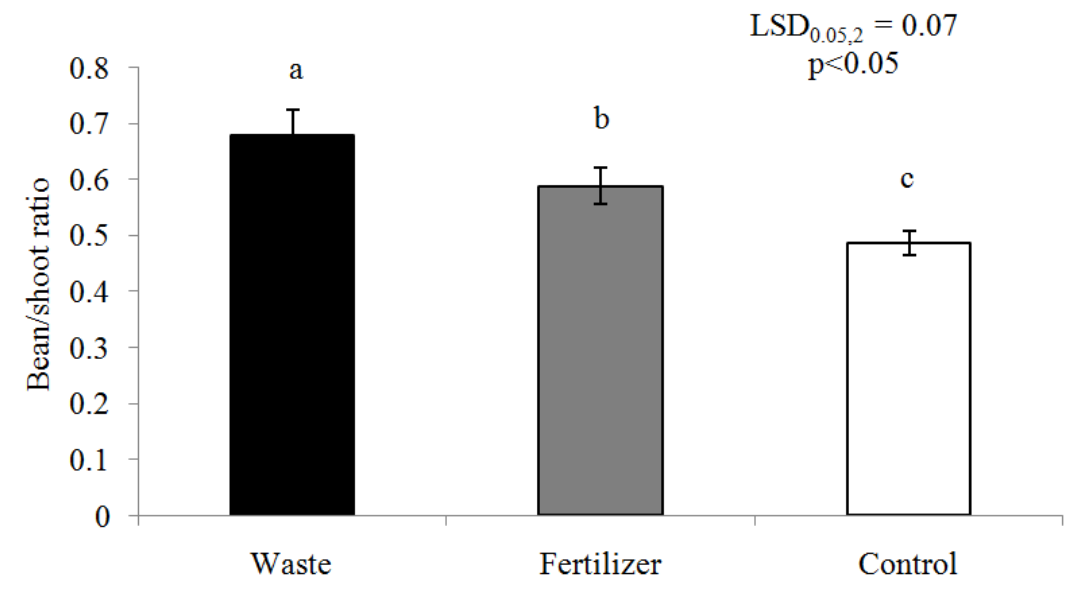

Fig. 4. Differences in bean/shoot ratio of snap bean treated with the fermentation waste, commercial P fertilizer treatments and control without $\mathrm{P}$ fertilizer. Different lowercase letters on histograms denote significant difference $(\mathrm{p}<0.05)$. $\mathrm{LSD}_{0.05,2}$ was 0.07 

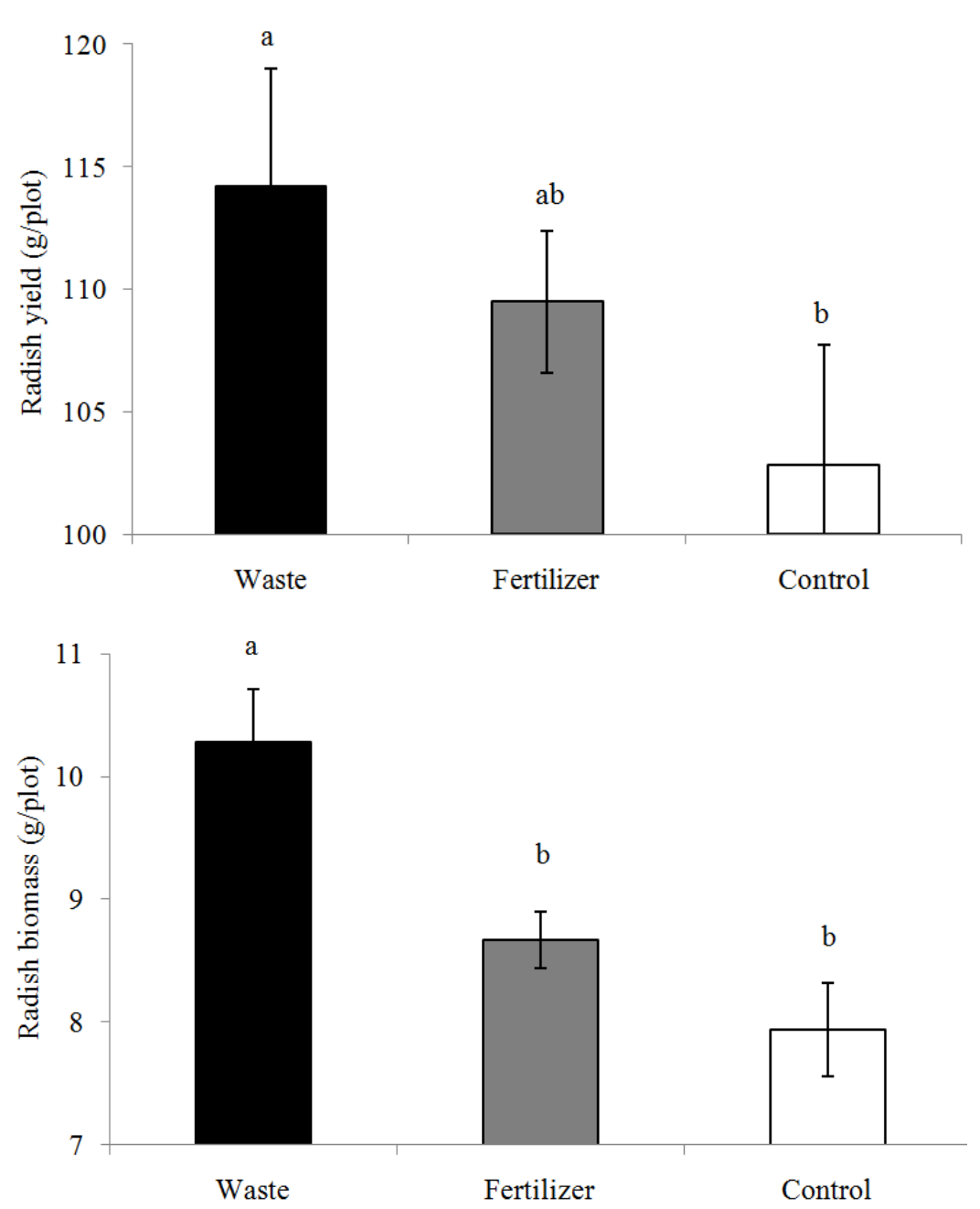

Fig. 5. Differences in radish yield and biomass treated with the fermentation waste, commercial P fertilizer treatments and control without $\mathrm{P}$ fertilizer. Different lowercase letters on histograms denote significant difference $(\mathrm{p}<0.05)$. $\mathrm{LSD}_{0.05,2}$ was 9.5 and 0.79 for radish yield and biomass, respectively

In commercial bioethanol production, every liter of ethanol can generate approximately 13 to 20 liters of liquid waste (Willington and Marten, 1982; Wilkie et al., 2000). If not treated properly, the generated waste can be a serious water pollutant (Sheehan and Greenfield, 1980; Ward and Singh, 2002). The data of this study show that the biofuel waste can be a valuable and alternative resource used as a $\mathrm{P}$ fertilizer and soil amendment. Specifically in Florida, one of the largest states for agriculture, it will not only be a solution for environmental sustainability, but also will gain economic benefits by converting the wastes to valuable fertilizers or soil amendments.

\section{Conclusion}

Our results of this preliminary study showed that the fermentation waste increased both yield and biomass of both snap bean and radish significantly.
Particularly, the waste increased the bean/shoot ratio of snap bean significantly and hence increase economic yield of the crop. Potentially, the fermentation wastes from bioenergy production may be used as an alternative of $P$ fertilizers. These data may provide an insight for a sustainable solution to deal with the rapid accumulation of fermentation wastes from biofuel production. Additionally, using the waste as an alternative $\mathrm{P}$ fertilizer source may also contribute to alleviating depletion of the nonrenewable mineral resource of phosphate rock over the world. More researches are needed to study the efficiency in large scale of these "waste fertilizers".

\section{Acknowledgement}

The Stan Mayfield Biorefinery Pilot Plant in Perry, Florida provided the fermentation waste for this study. 


\section{Author's Contributions}

Xiaolin Liao: Analyzed and interpreted the data and drafted the manuscript.

Ben Hogue: Based on the design, completed the study with radish and snap bean with Zhu.

Shouliang Zhu: Based on the design, completed the study with radish and snap bean with Hogue.

Zhaohui Tong: Processed the biofuel wastes and analyzed the Properties of the waste, discussed the design of the study with Liu and $\mathrm{Li}$, critically reviewed the manuscript.

Guodong Liu: Designed the research plan with $\mathrm{Li}$ and Tong and organized the study, finalized the manuscript.

Yuncong Li: Designed the study with Liu and Tong and critically reviewed the manuscript.

\section{Ethics}

This article is original and contains unpublished material. All of the other authors have read and approved the manuscript and there are no ethical issues involved.

\section{Reference}

Abelson, P.H., 1999. A potential phosphate crisis. Science, 283: 2015-2015.

DOI: $10.1126 /$ science. 283.5410 .2015

Buster, T.P., 1979. Soil Survey of Marion County area, Florida. 1st Edn., Soil Conservation Service, Washington, DC., pp: 148.

Callander, I.J., T.A. Clark, P.N. McFarlane and K.L. Mackie, 1986. Anaerobic digestion of stillage from a pilot scale wood-to-ethanol process I. Stillage characterisation. Environ. Technol. Lett., 7: 325-334. DOI: $10.1080 / 09593338609384419$

Cordell, D., J.O. Drangert and S. White, 2009. The story of phosphorus: Global food security and food for thought. Global Environ. Change, 19: 292-305. DOI: $10.1016 /$ j.gloenvcha.2008.10.009

Driessen, W.J.B.M., M.H. Tielbaard and T.L.F.M. Vereijken, 1994. Experience on anaerobic treatment of distillery effluent with the UASB process. Water Sci. Technol., 30: 193-201.

Galvez, A., T. Sinicco, M.L. Cayuela, M.D. Mingorance and F. Fornasier et al., 2012. Short term effects of bioenergy by-products on soil $\mathrm{C}$ and $\mathrm{N}$ dynamics, nutrient availability and biochemical properties. Agric. Ecosyst. Environ., 160: 3-14.

DOI: $10.1016 /$ j.agee.2011.06.015

Hubbard, M.R., 2001. Statistical Quality Control for the Food Industry. 2nd Edn., Springer Science and Business Media, Gaithersburg, ISBN-10: 0834220938, pp: 327.
Hoel, B.O., 1998. Use of a hand-held chlorophyll meter in winter wheat: Evaluation of different measuring positions on the leaves. Acta Agric. Scandinavica, 48: 222-228. DOI: 10.1080/09064719809362502

Ibeto, C.N., A.U. Ofoefule and K.E. Agbo, 2011. A global overview of biomass potentials for bioethanol production: A renewable alternative fuel. Trends Applied Sci. Res., 6: 410-425.

DOI: 10.3923/tasr.2011.410.425

Kim, S. and B.E. Dale, 2004. Global potential bioethanol production from wasted crops and crop residues. Biomass Bioenergy, 26: 361-375. DOI: 10.1016/j.biombioe.2003.08.002

Kolář, L., S. Kužel, J. Peterka, P. Štindl and V. Plát, 2008. Agrochemical value of organic matter of fermented wastes in biogas production. Plant Soil Environ., 54: 321-328.

Moore, A., 2011. Fertilizer Potential of Biofuel Byproducts. In: Biofuel Production-Recent Developments and Prosepects, Dr. Marco Aurellio Dos Santos Bernardes (Ed.), In Tech., pp: 437-450.

Mustafa, B., B. Havva and O. Cahide, 2008. Progress in bioethanol processing. Progress Energy Combust. Sci., 34: 551-573. DOI: 10.1016/j.pecs.2007.11.001

Olson, S.M., P.D. Dittmar, S. Webb, S. Zhang and S.A. Smith et al., 2013. Legume Production in Florida: Snapbean, Lima Bean, Southern Pea, Snowpea. In: Vegetable Production Book for Florida 2012-2013, Olson, S.M. (Ed.), University of Florida/IFAS Extension, Gainesville, Florida, pp: 143-162.

Ozores-Hampton, M., P.D. Dittmar, S. Webb, R.N. Raid and E.J. McAvoy, 2013. Legume Production in Florida: Snapbean, Lima Bean, Southern Pea, Snowpea. In: Vegetable Production Book for Florida 2012-2013, Olson, S.M. (Ed.), University of Florida/IFAS Extension, Gainesville, Florida, pp: 261-268.

Postelwait, J., 2013. Florida biofuels project makes cellulosic ethanol on commercial scale. Electric Light and Powergrid International.

Percival, G.C., I.P. Keary and K. Noviss, 2008. The potential of a chlorophyll content SPAD meter to quantify nutrient stress in foliar tissue of Sycamore (Acer pseudoplatanus), English Oak (Quercus robur) and European Beech (Fagus sylvatica). Arboric. Urban Forestry, 34: 89-100.

Rainey, T.J., W.O.S. Doherty, J.R. Brown, D.M. Martinez and N.A. Kelson, 2009. Experimental study of Australian sugarcane bagasse pulp permeability. Appita J., 62: 296-302.

Sahai, R., S. Jabeen and P.K. Saxena, 1983. Effect of distillery waste on seed germination, seedling growth and pigment content of rice. Ind. J. Ecol., 10: 7-10. 
SAS Institute, 2009. SAS ® 9.2 Macro language: Reference. SAS Institute Inc., Cary, NC.

Sheehan, G.J. and P.F. Greenfield, 1980. Utilisation, treatment and disposal of distillery wastewater. Water Res., 14: 257-277.

DOI: 10.1016/0043-1354(80)90097-4

Turner, F.T. and M.F. Jund, 1994. Assessing the nitrogen requirements of rice crops with a chlorophyll meter. Australian J. Exp. Agric., 34: 1001-1005. DOI: 10.1071/EA9941001

Vijayaraghavan, V. and Y.S. Yun, 2007. Utilization of fermentation waste (Corynebacterium glutamicum) for biosorption of Reactive Black 5 from aqueous solution. J. Hazardous Mater., 141: 45-52. DOI: 10.1016/j.jhazmat.2006.06.081

Wang, L., Z. Tong., G.D. Liu and Y.C. Li, 2014. Characterization of biomass residues and their amendment effects on water sorption and nutrient leaching in sandy soil. Chemosphere, 107: 354-359. DOI: 10.1016/j.chemosphere.2013.12.088

Ward, O. and A. Singh, 2002. Bioethanol technology: Developments and perspectives. Adv. Applied Microbiol., 51: 53-80. DOI: $10.1016 / \mathrm{S} 0065-2164(02) 51001-7$

Wilkie, A.C., K.J. Riedesel and J.M. Owens, 2000. Stillage characterization and anaerobic treatment of ethanol stillage from conventional and cellulosic feedstocks. Biomass Bioenergy, 19: 62-102.

DOI: $10.1016 / \mathrm{S} 0961-9534(00) 00017-9$
Willington, I.P. and G.G. Marten, 1982. Options for handling stillage waste from sugar-based fuel ethanol production. Resources Conservat., 8: 111-129. DOI: 10.1016/0166-3097(82)90036-0

Wood, C.W., D.W. Reeves, R.R. Duffield and K.L. Edmisten, 1992. Field chlorophyll measurements for evaluation of corn nitrogen status. J. Plant Nutr., 15: 487-501. DOI: 10.1080/01904169209364335

Wyman, C.E., B.E. Dale, R.T. Elander, M. Holtzapple and M.R. Ladisch et al., 2005. Coordinated development of leading biomass pretreatment technologies. Bioresource Technol., 96: 1959-1966. DOI: $10.1016 /$ j.biortech.2005.01.010

Zeng, J., Z. Tong, L. Wang, J.Y. Zhu and L. Ingram, 2014. Isolation and structural characterization of sugarcane bagasse lignin after dilute phosphoric acid plus steam explosion pretreatment and its effect on cellulose hydrolysis. Bioresource Technol., 154: 274-81. DOI: 10.1016/j.biortech.2013.12.072

Zotarelli, L, M.D. Dukes, J.M.S. Scholberg, K. Femminella and R. Muñoz-Carpena, 2011. Irrigation scheduling for green bell peppers using capacitance soil moisture sensors. J. Irrigat. Drainage Eng., 137: 73-81.

DOI: 10.1061/(ASCE)IR. 1943-4774.0000281 